\title{
MANAJEMEN BERBASIS MADRASAH DALAM PENINGKATAN MUTU DI MTsN WATAMPONE KABUPATEN BONE
}

\author{
Oleh: Fajri Dwiyama \\ Dosen IAIN Bone
}

\begin{abstract}
This study aims to provide an overview of madrasah-based management in Madrasah Tsanawiyah Negeri 1 Watampone, and madrasahbased management in improving the quality of Madrasah Tsanawiyah Negeri 1 Watampone. This research is a type of qualitative research. The source of the research data was the head of the madrasah, the deputy head of the madrasah curriculum section, the deputy head of the madrasah in the infrastructure facility, the deputy head of the madrasah in the student section, the deputy head of the madrasah in the public relations department, the teacher, and the school committee. Data collection techniques used are observation, interviews, and documentation. The collected data is analyzed through steps of data reduction, data presentation, and data verification. The results of the study found that madrasah-based management in Madrasah Tsanawiyah Negeri 1 Watampone has been carried out well, through planning stages with the preparation of work programs and budget plans involving all madrasa components. The implementation of the work program is carried out according to each division of labor. Madrasa leadership is carried out by the head of the madrasah. Supervision and evaluation are carried out to ensure that all activities are carried out properly and as a reference for further improvements. Madrasah information systems are used to obtain information on the development of education. Quality improvement in Madrasah Tsanawiyah Negeri 1 Watampone is carried out by meeting all national standards of education criteria and improving student achievement. In fulfilling the criteria for standard nasinonal education, it is ensured by carrying out all activities related to this matter through the leadership of a strong madrasa head, good cooperation between madrasah components, and fulfillment of professional duties and responsibilities.
\end{abstract}

Kata Kunci: Management, Quality, Madrasah 


\section{A. Pendahuluan}

\section{Latar Belakang}

Salah satu strategi kebijakan pemerintah dalam meningkatkan kualitas sumber daya manusia Indonesia adalah melalui peningkatan mutu pendidikan. Sejalan dengan perkembangan abad 21, yang di kenal dengan era globalisasi maka diperlukan profesionalisme di segala bidang termasuk dunia pendidikan. Dalam bidang pendidikan, Indonesia dewasa ini paling sedikit menghadapi tiga persoalan yang serius. Pertama, krisis moral yang begitu dahsyat di dalam masyarakat. Kedua, sistem pembelajaran yang belum begitu memadai di madrasah-madrasah. Ketiga, mutu pendidikan yang masih rendah khususnya di jenjang pendidikan dasar dan menengah.

Agar mampu berperan dalam persaingan global, maka sebagai bangsa kita perlu terus mengembangkan dan meningkatkan kualitas sumber daya manusia. Oleh karena itu, peningkatan kualitas sumber daya manusia merupakan kenyataan yang harus dilakukan secara terencana, terarah, intensif, efektif dan efisien dalam proses pembangunan, kalau tidak ingin bangsa ini kalah bersaing dalam menjalani persaingan global tersebut.

Dari uraian di atas, dapat dipahami bahwa pembangunan pendidikan bukan hanya terfokus pada penyediaan faktor input pendidikan, tetapi juga harus lebih memperhatikan faktor proses pendidikan. Input pendidikan merupakan hal yang mutlak harus ada dalam batas-batas tertentu, tetapi input tersebut tidak menjamin dapat meningkatkan mutu pendidikan secara otomatis.

Menyadari hal tersebut, pemerintah telah melakukan upaya penyempurnaan sistem pendidikan. Diantara upaya tersebut, antara lain dengan dikeluarkannya Undang-Undang Nomor 22 dan 25 Tahun 1999 tentang Otonomi Daerah, yang secara langsung berpengaruh terhadap 
perencanaan, pelaksanaan dan evaluasi pendidikan. Bila sebelumnya pengelolaan pendidikan merupakan wewenang pusat, maka dengan berlakunya undang-undang tersebut kewenangan berada pada pemerintah daerah, kota/kabupaten. Pemberlakuan sistem pendidikan otonomi, pada dasarnya merupakan kesempatan bagi lembaga pendidikan untuk mengelola sendiri lembaga pendidikannya tanpa ada campur tangan dari pemerintah secara menyeluruh. Akan tetapi, untuk dapat melaksanakannya perlu didukung sumber daya manusia yang berkualitas dan mampu berfikir dengan sistematis.

Pemikiran itu telah mendorong munculnya pendekatan baru, yakni pengelolaan peningkatan mutu pendidikan dalam kegiatan pendidikan. Pendekatan ini kemudian dikenal dengan Manajemen Peningkatan Mutu Berbasis Madrasah. Secara umum, manajemen peningkatan mutu berbasis madrasah dapat diartikan sebagai model manajemen yang memberikan otonomi lebih besar kepada madrasah dan mendorong pengambilan keputusan secara partisipatif yang melibatkan secara langsung warga madrasah (orang tua siswa, tokoh masyarakat, ilmuwan, pengusaha, dsb) untuk meningkatkan mutu madrasah berdasarkan kebijakan pendidikan nasional. Dengan pendekatan ini madrasah memiliki kewenangan dalam mengembangkan program-program yang sesuai dengan kebutuhan dan potensi yang dimilikinya. Dengan fleksibilitas madrasah akan lebih aktif dalam mengelola sumber daya madrasah secara lebih optimal.

MTsN 1 Watampone yang terletak di jalan Sukawati Kabupaten Bone merupakan salah satu madrasah yang telah melaksanakan manajemen peningkatan mutu berbasis madrasah. MTsN 1 Watampone merupakan salah satu madrasah model yang berada di kota Watampone dan memiliki semangat untuk mengembangkan dan melaksanakan Manajemen 
Peningkatan Mutu Berbasis Madrasah. MTsN 1 Watampone juga berkeinginan dapat mendukung proses reformasi yang ada di lingkungan pendidikan untuk meningkatkan mutu pendidikan. Dengan pengaturan manajemen madrasah yang semakin baik, MTsN 1 Watampone berusaha menjadikan madrasah menjadi lembaga yang mampu mencetak peserta didik yang bermutu dan mampu bersaing ditengah proses informatisasi dan persaingan global yang semakin pesat.

\section{Rumusan Masalah}

Berdasarkan latar belakang tersebut, maka penulis dapat merumuskan permasalahan penelitian sebagai berikut:

1. Bagaimana manajemen berbasis madrasah di MTsN 1 Watampone ?

2. Bagaimana manajemen berbasis madrasah dalam peningkatan mutu di MTsN 1 Watampone?

\section{Hubungan dengan Penelitian Sebelumnya}

Pembahasan yang dipaparkan dalam penelitian ini adalah pemaparan yang mendeskripsikan tentang manajemen berbasis madrasah dalam peningkatan mutu di Madrasah Tsanawiyah Negeri 1 Watampone Kabupaten Bone. Pokok masalah yang akan dikaji memiliki keterkaitan dengan hasil penelitian yang telah dilakukan beberapa peneliti sebelumnya. Oleh karena itu, peneliti mengungkapkan hasil penelitian yang dianggap memiliki hubungan dengan penelitian ini, baik hasil penelitian dalam bentuk tesis, maupun hasil penelitian dalam bentuk yang lainnya.

Penelitian yang dilakukan oleh Iskandar Idi dalam tesisnya dengan judul "Madrasah Model Sebagai Alternatif Peningkatan Mutu Madrasah; Studi tentang Pengembangan Madrasah di Sulawesi Selatan”. Penelitiannya menyimpulkan bahwa madrasah model adalah suatu bentuk pembinaan

madrasah yang dilaksanakan berdasarkan penajaman skala prioritas untuk 
meningkatkan mutu madrasah secara keseluruhan, dan problem mendasar yang dialami madrasah adalah muatan kurikulumnya terlalu berat, gurunya kurang kuantitas dan kualitas, pengajaran agamanya sangat sedikit, sarana dan prasarananya sangat tidak memadai. ${ }^{1}$ Hubungan dengan penelitian penulis dalam tesis ini, akan ditelusuri bagaimana pengelolaan manajemen mutu pada madrasah dengan melihat implementasi muatan kurikulum, tenaga guru dan sistem pengajarannya, serta sarana dan prasarana yang mendukung peningkatan mutu madrasah.

Hasil penelitian Tety Yuliana dalam tesisnya yang berjudul "Kemampuan Kepala Madrasah dalam Implementasi Manajemen Peningkatan Mutu Berbasis Madrasah Studi Kasus di SMP Negeri 2 Brebes". ${ }^{2}$ Adapun perbedaan antara penelitian yang telah dilakukan oleh saudari Tety Yuliana dengan penelitian yang penulis lakukan yaitu penelitian yang dilakukan oleh Tety Yuliana difokuskan pada manajemen peningkatan mutu yang dilakukan oleh kepala madrasah, sedangkan penelitian yang akan penulis lakukan adalah menyangkut manajemen berbasis madrasah dalam peningkatan mutu yang melibatkan semua pihak di Madrasah Tsanawiyah Negeri Watampone Kabupaten Bone.

\section{Landasan Teori}

\section{Konsep Manajemen Berbasis Madrasah}

Istilah Manajemen berbasis Madrasah merupakan terjemahan dari School Based Management. Istilah ini pertama kali muncul di Amerika

${ }^{1}$ Iskandar Idy, Madrasah Sebagai Alternatif Peningkatan Mutu Madrasah; Studi Tentang Pengembangan Madrasah di Sulawesi Selatan "Tesis Magister" (Makassar: PPs Universitas Muslim Indonesia, 2002), h. 7

${ }^{2}$ Yuliana Tety, Kemampuan Kepala Sekolah dalam Implementasi Manajemen Peningkatan Mutu Berbasis Sekolah Studi Kasus di SMP Negeri 2 Brebes, (Semarang: Tesis Manajemen Pendidikan, PPs Universitas Negeri Semarang, 2006), h. 7 
Serikat ketika masyarakat mulai mempertanyakan relevansi pendidikan dengan tuntutan dan perkembangan masyarakat setempat. ${ }^{3}$

Menurut Nanang Fatah Manajemen berbasis madrasah merupakan pendekatan politik yang bertujuan untuk mendesain ulang pengelolaan madrasah dengan memberikan kekuasaan kepada kepala madrasah dan meningkatkan partisipasi masyarakat dalam upaya perbaikan kinerja madrasah yang mencakup guru, siswa, komite madrasah, orang tua siswa dan masyarakat. Manajemen berbasis Madrasah mengubah sistem pengambilan keputusan dengan memindahkan otoritas dalam pengambilan keputusan dan manajemen ke setiap yang berkepentingan di tingkat lokal local stakeholder. ${ }^{4}$

Menurut Undang-undang Republik Indonesia Tahun 2003 tentang Sisdiknas pasal 51 ayat 1, Manajemen berbasis madrasah adalah bentuk otonomi manajemen pendidikan pada satuan pendidikan, yang dalam hal ini kepala madrasah dan guru dibantu oleh komite madrasah dalam mengelola kegiatan pendidikan. Jadi dapat disimpulkan bahwa manajemen berbasis madrasah merupakan sebuah strategi untuk memajukan pendidikan dengan mentransfer keputusan penting memberikan otoritas dari negara dan pemerintah daerah kepada individu pelaksana di madrasah. Manajemen berbasis madrasah menyediakan kepala madrasah, guru, siswa, dan orang tua kontrol yang sangat besar dalam proses pendidikan dengan memberi mereka tanggung jawab untuk memutuskan anggaran, personil, serta kurikulum.

Pelaksanaan manajemen berbasis madrasah, tidaklah serta merta dilakukan begitu saja tanpa didasari oleh peraturan perundang-undangan

${ }^{3}$ Ibtisam Abu Duhou, School Based Management, (Jakarta:Kencana 2004) h.7

${ }^{4}$ Nanang Fatah, Konsep Manajemen berbasis Sekolah dan Dewan Sekolah. (Bandung: Pustaka Bani Quraisy 2003) h.8 
yang berlaku. Manajemen berbasis madrasah didasari oleh Undang-undang Otonomi Daerah No. 32 Tahun 2004 pasal 1 ayat 5: Dijelaskan bahwa otonomi daerah adalah hak, wewenang, dan kewajiban daerah otonom untuk mengatur dan mengurusi urusan pemerintahan dan kepentingan masyarakat setempat sesuai dengan peraturan perundang-undangan.

Jadi dapat disimpulkan bahwa manajemen berbasis madrasah merupakan sebuah strategi untuk memajukan pendidikan dengan mentransfer keputusan penting memberikan otoritas dari negara dan pemerintah daerah kepada individu pelaksana di madrasah. Manajemen berbasis madrasah menyediakan kepala madrasah, guru, siswa, dan orang tua kontrol yang sangat besar dalam proses pendidikan dengan memberi mereka tanggung jawab untuk memutuskan anggaran, personil, serta kurikulum.

E Mulyasa mengatakan bahwa tujuan utama manajemen berbasis madrasah adalah meningkatkan efisiensi, mutu, dan pemerataan pendidikan. ${ }^{5}$ Peningkatan efisiensi diperoleh melalui keleluasaan mengelola sumber daya yang ada, partisipasi masyarakat, dan penyederhanaan birokrasi. Peningkatan mutu diperoleh melalui partisipasi orang tua, kelenturan pengelolaan madrasah, peningkatan profesionalisme guru, adanya hadiah dan hukuman sebagai kontrol, serta hal lain yang dapat menumbuh kembangkan suasana yang kondusif.

Madrasah yang menerapkan manajemen berbasis madrasah mempunyai dorongan dan harapan yang tinggi untuk meningkatkan prestasi peserta didik dan madrasahnya. Kepala madrasah memiliki komitmen dan motivasi yang kuat untuk meningkatkan mutu madrasah secara optimal. Guru memiliki komitmen dan harapan yang tinggi bahwa anak didiknya

${ }^{5}$ E. Mulyasa, Manajemen Berbasis Sekolah, (Jakarta:Rosda 2004), cet ke.7, h.13 
dapat mencapai tingkat prestasi yang maksimal, walaupun dengan segala keterbatasan sumber daya pendidikan yang ada di madrasah. Sedang peserta didik juga mempunyai motivasi untuk selalu meningkatkan diri untuk berprestasi sesuai dengan bakat dan kemampuannya. Harapan tinggi dari ketiga unsur madrasah ini merupakan salah satu faktor yang menyebabkan madrasah selalu dinamis untuk selalu menjadi lebih baik dari keadaan sebelumnya.

Penerapan manajemen berbasis madrasah meliputi lima komponen, yakni: perencanaan program, pelaksanaan program, kepemimpinan kepala madrasah, pengawasan/evaluasi, dan sistem informasi madrasah. ${ }^{6}$ Dalam perencanaan program madrasah, kepala madrasah bersama-sama dengan stekholdernya dalam merumuskan langkah-langkah strategis pengembangan madrasah dan penyelenggaraan pendidikan, seperti: merumuskan visi misi dan tujuan madrasah sesuai dengan kebutuhan masyarakat yang mengarah kepada pencapaian tujuan pendidikan. Selanjutnya merumuskan rencana kerja tahunan yang memuat ketentuan jelas mengenai: kesiswaan, kurikulum dan kegiatan pembelajaran, pendidikan dan tenaga kependidikan, sarana dan prasarana, keuangan dan pembiayaan, budaya, dan lingkungan madrasah, peran serta masyarakat dan kemitraan, serta rencana-rencana kerja lain yang mengarah pada peningkatan dan pengembangan mutu.

Pelaksanaan kegiatan madrasah meliputi: bidang kesiswaan, bidang kurikulum dan kegiatan pembelajaran, bidang pendidik dan tenaga kependidikan, bidang sarana dan prasarana, bidang keuangan dan pembiayaan, budaya dan lingkungan madrasah, peran serta masyarakat dan

\footnotetext{
${ }^{6}$ Husaini Usman, Manajemen Teori, Praktik, dan Riset Pendidikan, Edisi 3. Cet. 11, (Jakarta: Bumi Aksara, 2010), h. 5
} 
kemitraan madrasah. Bidang-bidang tersebut memiliki tanggung jawab masing-masing yang dipantau oleh kepala madrasah.

Kepemimpinan madrasah adalah suatu kegiatan mengarahkan, memengaruhi, dan mengendalikan seluruh potensi madrasah yang dilakukan oleh seorang kepala madrasah secara sistematik dan terprogram dalam rangka mencapai tujuan organisasi. Syaiful sagala menjelaskan bahwa dalam manajemen berbasis madrasah, kepala madrasah bersama dewan guru dan warga madrasah lainnya secara mandiri, transparan, dan bertanggung jawab melaksanakan program madrasah untuk mencapai visi, misi dan target mutu yang diamanatkan oleh masyarakat dan semua pihak yang berkepentingan terhadap pendidikan dimadrasah yang bersangkutan. ${ }^{7}$

Pengawasan pengelolaan madrasah merupakan rangkaian kegiatan pemantauan, supervisi, pelaporan dan tindak lanjut hasil pengawasan. Kegiatan ini dilakukan secara terstruktur yang dimulai dari tingkat yang paling rendah (satuan pendidikan) sampai ketingkat yang lebih tinggi.

\section{Peningkatan Mutu Pendidikan}

Menurut Oemar Hamalik, Pengertian mutu dapat dilihat dari dua sisi, yaitu segi normatif dan segi deskriptif, dalam artian normatif, mutu ditentukan berdasarkan pertimbangan (kriteria) intrinsik dan ekstrinsik. ${ }^{8}$ Berdasarkan kritria intrisik, mutu pendidikan merupakan produk pendidikan yakni manusia yang terdidik sesuai dengan standar ideal. Berdasarkan kriteria ekstrinsik, pendidikan merupakan instrumen untuk mendidik tenaga

${ }^{7}$ Syaiful Sagala, Manajemen Strategik dalam Peningkatan Mutu Pendidikan, (Bandung: Alfabeta, 2011), h. 174

${ }^{8}$ Oemar Hamalik, Evaluasi kurikulum, (Bandung: Remaja Rosda Karya,1990), h.33 
kerja yang terlatih. Dalam artian deskriptif, mutu ditentukan berdasarkan keadaan senyatanya, misalkan hasil tes prestasi belajar.

Mutu pendidikan tidak saja ditentukan oleh madrasah sebagai lembaga pengajaran, tetapi juga disesuaikan dengan apa yang menjadi pandangan dan harapan masyarakat yang cenderung selalu berkambang seiring dengan kemajuan zaman. Bertitik tolak pada kecendrungan ini penilaian masyarakat tentang mutu lulusan madrasah pun terus berkembang. Karena itu madrasah harus terus menerus meningkatkan mutu lulusannya dengan menyesuaikannya dengan perkembangan tuntutan masyarakat menuju pada mutu pendidikan yang dilandasi tolak ukur norma ideal.

Acuan mutu yang digunakan untuk pencapaian atau pemenuhan mutu pendidikan pada satuan pendidikan adalah Standar Nasional Pendidikan (SNP) dan standar-standar lain yang disepakati oleh kelompok masyarakat. Standar nasional pendidikan adalah standar yang dibuat oleh pemerintah, sedangkan standar lain adalah standar yang dibuat oleh satuan pendidikan dan/atau lembaga lain yang dijadikan acuan oleh satuan pendidikan. ${ }^{9}$ Standar-standar lain yang disepakati oleh kelompok masyarakat digunakan setelah standar nasional pendidikan dipenuhi oleh satuan pendidikan sesuai dengan kekhasan jalur, jenjang, dan jenis pendidikan.

Korelasi mutu dengan pendidikan, sebagaimana pengertian yang dikemukakan oleh Dzaujak Ahmad, bahwa mutu pendidikan adalah kemampuan madrasah dalam pengelolaan secara operasional dan efisien tehadap komponen-komponen yang berkaitan dengan madrasah sehingga menghasilkan nilai tambah terhadap komponen tersebut menurut

\footnotetext{
${ }^{9}$ Pusat Penjaminan Mutu Pendidikan, Pedoman Pemenuhan Standar Nasional Pendidikan pada Sekolah Menengah Pertama Madrasah Tsanawiyah, (Badan Pengembangan Sumberdaya Manusia Pendidikan dan Kebudayaan dan Penjaminan Mutu Pendidikan, Kementerian Pendidikan dan Kebudayaan, 2012), h. 12
} 
norma/standar yang berlaku. ${ }^{10}$ Mutu pendidikan harus diupayakan untuk mencapai kemajuan yang dilandasi oleh suatu perubahan terencana. Peningkatan mutu pendidikan diperoleh melalui dua strategi, yaitu peningkatan mutu pendidikan yang berorientasi akademis untuk memberi dasar minimal dalam perjalanan yang harus ditempuh mencapai mutu pendidikan yang dipersyaratkan oleh tuntutan zaman, dan peningkatan mutu pendidikan yang berorientasi pada keterampilan hidup yang esensial yang dicakupi oleh pendidikan yang berlandasan luas, nyata dan bermakna.

Standar Nasional Pendidikan sebagaimana yang diatur dalam Peraturan Pemerintah Nomor 19 Tahun 2005 tentang Standar Nasional Pendidikan dan peraturan perundangan lain yang relevan yaitu kriteria minimal tentang sistem pendidikan di seluruh wilayah hukum Negara Kesatuan Republik Indonesia. SNP dipenuhi oleh satuan atau program pendidikan dan penyelenggara satuan atau program pendidikan secara sistematis dan bertahap dalam kerangka jangka menengah yang ditetapkan dalam rencana strategis satuan atau program pendidikan. Ruang lingkup standar nasional pendidikan yang dimaksud meliputi delapan standar yaitu: standar isi, standar proses, standar kompetensi lulusan, standar kompetensi pendidik dan tenaga kependidikan, standar sarana dan prasarana, standar pengelolaan, standar pembiayaan, standar penilaian. ${ }^{11}$

Delapan Standar Nasional Pendidikan di atas memiliki keterkaitan satu sama lain dan sebagian standar menjadi prasyarat bagi pemenuhan standar yang lainnya. Dalam kerangka sistem, komponen input sistem pemenuhan Standar Nasional Pendidikan adalah Standar Kompetensi

\footnotetext{
${ }^{10}$ Dzaujak Ahmad, Penunjuk Peningkatan Mutu pendidikan di sekolah Dasar, (Jakarta: Depdikbud 1996), h.8

${ }^{11}$ Tim, Peningkatan Manajemen Melalui Penguatan Tata Kelola dan Akuntabilitas di Sekolah/Madrasah, (Jakarta: Kemendiknas dan Kemenag RI, 2011), h 192
} 
Pendidik dan Tenaga Kependidikan (PTK), Standar Pengelolaan, Standar Sarana dan Prasarana (Sarpras), dan Standar Pembiayaan. Bagian yang termasuk pada komponen proses adalah Standar Isi, Standar Proses, dan Standar Evaluasi, sedangkan bagian yang termasuk pada komponen output adalah Standar Kompetensi Lulusan.

\section{B. Metode Penelitian}

Jenis penelitian yang digunakan dalam penelitian ini adalah penelitian kualitatif, karena penelitiannya dilakukan pada kondisi yang alamiah obyek penelitiaanya berkembang sebagaimana yang terjadi, tidak dimanipulasi dan kehadiran peneliti tidak mempengaruhi dinamika obyek yang diteliti. Penelitian ini bersifat deskriptif yaitu penelitian yang dimaksudkan untuk mengumpulkan informasi mengenai status suatu gejala yang ada, yaitu keadaan gejala menurut apa adanya pada saat penelitian dilakukan. ${ }^{12}$ Penelitian ini akan meneliti implementasi manajemen peningkatan mutu berbasis madrasah di MTsN 1 Watampone Kabupaten Bone. Penelitian ini menggunakan data primer dan data skunder diperoleh dengan teknik observasi dan teknik wawancara tentang unsur-unsur yang terdapat dalam paradigma penelitian. Sedangkan data sekunder diperoleh dengan teknik dokumentasi.

Adapun lokasi penelitian ini adalah MTsN Watampone Kabupaten Bone yang beralamat di Jalan Sukawati Kota Watampone Kabupaten Bone. Adapun alasan peneliti meneliti di lembaga pendidikan tersebut karena lembaga ini telah menerapkan manajemen berbasis madrasah, khususnya dalam peningkatan mutu.

${ }^{12}$ Suharsimi Arikunto, Manajemen Penelitian, (Jakarta: Rineka Cipta, 2005), h. 234 
Populasi dalam penelitian ini berjumlah 1900 orang yang terdiri dari Kepala MTsN 1 Watampone, 120 orang guru, 35 orang tenaga kependidikan, 1.739 orang siswa, dan 1 orang komite madrasah. Dalam penelitian ini peneliti menggunakan teknik pengambilan sampel non probability sampling yakni teknik pengambilan sampel yang tidak memberikan peluang sama bagi setiap anggota sampel. Jenis teknik yang dipakai adalah purposive sampling yaitu teknik pengambilan sampel sumber data dengan pertimbangan tertentu. Pertimbangan tertentu ini, misalnya orang tersebut dianggap paling tahu tentang apa yang kita harapkan, atau mungkin dia sebagai penguasa sehingga akan memudahkan peneliti menjelajahi obyek/situasi sosial yang diteliti. Sampel dalam penelitian ini adalah kepala sekolah, wakil kepala madrasah, pendidik, tenaga kependidikan, dan komite sekolah di MTsN 1 Watampone Kabupaten Bone.

Metode pengumpulan data dilakukan melalui observasi, wawancara dan dokumentasi. Adapun analisis data dilakukangan melalui reduksi data, display data, dan perifikasi data atau penarikan kesimpulan.

\section{Hasil Penelitian dan Pembahasan}

Madrasah Tsanawiyah Negeri (MTsN) 1 Watampone Kabupaten Bone merupakan salah satu madrasah di Kabupaten Bone yang beralamat di jalan Letjend. Soekawati Kelurahan Manurunge Kecamatan Tanete Riattang. Keberadaan MTsN 1 Watampone sudah cukup lama, dimana penyelenggaraan pendidikan dimulai sejak tanggal 08 November 1969 dan berdiri di bawah naungan Kementerian Agama. MTsN Watampone dijadikan Madrasah Negeri berdasarkan dengan Surat Keputusan Menteri Agama Republik Indonesia No. 158 Tahun 1969 tanggal 8 Nopember 1969.

Letak MTsN Watampone ditinjau secara geografis sangatlah strategis, yaitu tepat berada di jantung kota Watampone sehingga madrasah 
tersebut mudah dijangkau dari segala arah melalui transportasi darat. Karena letaknya yang sangat strategis, dan ditunjang dengan mutu yang tinggi, serta pelaksanaan manajemen berbasis madrasah yang baik, sehingga setiap tahunnya MTsN 1 Watampone diminati oleh banyak siswa baru yang jumlahnya mencapai ratusan. Berikut penjabaran manajemen berbasis madrasah dalam peningkatan mutu di Madrasah Tsanawiyah Negeri 1 Watampone Kabupaten Bone.

\section{Manajemen Berbasis Madrasah di MTsN 1 Watampone}

Pelaksanaan Manajamen Berbasis Madrasah di Madrasah Tsanawiyah Negeri 1 Watampone dilakukan melalui beberapa tahapan yaitu tahapan perencanaan, pelaksanaan, pengawasan, dan evaluasi, serta adanya kepemimpinan madrasah dan sistem informasi. Pada tahapan perencanaan dilakukan penyusunan visi, misi, dan tujuan Madrasah Tsanawiyah Negeri 1 Watampone yang disusun dengan melibatkan berbagai komponen madrasah seperti kepala madrasah, wakil kepala madrasah, dewan guru, dan komite madrasah.

Proses perencanaan di Madrasah Tsanawiyah Negeri 1 Watampone dilakukan secara terbuka dan melibatkan masyarakat dalam pengelolaan madrasah. Keterbukaan dalam pengelolaan madrasah dilakukan dengan cara melibatkan guru, tenaga kependidikan, dan komite madrasah dalam penyusunan visi, misi, tujuan, dan program kerja madrasah. Partisipasi guru, tenaga kependidikan dan masyarakat yang kuat mendorong percepatan pembangunan dalam segala bidang di Madrasah Tsanawiyah Negeri 1 Watampone.

Visi, misi, dan tujuan madrasah merupakan landasan kegiatan serta cita-cita yang ingin dicapai oleh Madrasah Tsanawiyah Negeri 1 Watampone dalam rangka peningkatan mutu dan mewujudkan tujuan pendidikan 
nasional. Untuk itu program kerja disusun dan dilaksanakan untuk tercapainya visi, misi, dan tujuan madrasah. Pelaksanaan program kerja dilaksankan secara profesional oleh kepala madrasah, wakil kepala madrasah, pendidik, dan tenaga kependidikan. Pelaksanaan program kerja dilakukan sesuai dengan tugas dan tanggung jawab dari masing-masing komponen madrasah. Kepala madrasah bertanggung jawab mengatur, memantau dan mengevaluasi program kerja. Pendidik bertugas melaksanakan program kerja yang berhubungan dengan proses pembelajaran. Sedangkan tenaga kependidikan bertugas dan bertanggung jawab terhadap pengelolaan madrasah.

Kepemimpinan madrasah di Madrasah Tsanawiyah Negeri 1 Watampone, dilakukan oleh kepala madrasah. Kepemimpinan madrasah ditujukan untuk mengawal, mengontrol, dan mengevaluasi ketercapaian program kerja. Dalam melaksanakan kepemimpinan madrasah, Kepala Madrasah Tsanawiyah Negeri 1 Watampone memiliki pribadi yang tegas, disiplin, dan ramah terhadap bawahannya serta memiliki kemampuan manajerial yang baik. Dalam kepemimpinannya Kepala Madrasah Tsanawiyah Negeri 1 Watampone mampu menjalankan tugasnya dengan baik yakni melakukan perencanaan program madrasah, mengarahkan, melakukan pengawasan, dan melakukan evaluasi.

Salah satu komponen manajemen berbasis madrasah lainnya di Madrasah Tsanawiyah Negeri 1 Watampone adalah pengawasan dan evaluasi. Kegiatan pengawasan dilakukan oleh kepala madrasah dalam bentuk pemantauan pelaksanaan program kerja, melakukan supervisi pembelajaran dan melakukan tindak lanjut terhadap hasil pengawasan. Adapun kegiatan evaluasi dilakukan oleh kapala madrasah untuk mengukur, menilai kinerja dan dan melakukan perbaikan. 
Madrasah Tsanawiyah Negeri 1 Watampone memiliki fasilitas sistem informasi, seperti komputer dan jaringan internet dalam mendukung manajemen berbasis madrasah di era informasi ini. Akan tetapi Madrasah Tsanawiyah Negeri 1 Watampone belum memiliki sistem informasi luas seperti website resmi madrasah yang dapat diakses oleh masyarakat luas. Namun untuk memperoleh informasi mengenai perkembangan pendidikan melalui internat sudah dapat dilakukan karena sudah tersedia jaringan yang dapat terhubung dengan internet.

\section{Manajemen berbasis madrasah dalam peningkatan mutu di MTsN 1 Watampone}

Manajemen berbasis madrasah dalam peningkatan mutu di Madrasah Tsanawiyah negeri 1 Watampone telah dilaksanakan dengan baik dan memperoleh akreditasi dengan peringkat A dari BAN-SM. Keberhasilan tersebut diperoleh karena Madrasah Tsanawiyah Negeri 1 Watampone menerapkan dan memenuhi semua komponen standar nasional pendidikan sebagai acuan mutu pendidikan. Adapaun standar tersebut yaitu: standar isi, standar proses, standar kompetensi lulusan, standar kompetensi pendidik dan tenaga kependidikan, standar sarana prasarana, standar pengelolaan, standar pembiayaan, dan standar penilaian. Selain standar tersebut di tambah juga dengan peningkatan prestasi peserta didik.

Kegiatan pemenuhan standar isi berupa pengembangan kurikulum, pelaksanaan kurikulum, kegiatan ekstrakurikuler dan kegiatan bimbingan konseling. Pengembangan kurikulum dilakukan tiap tahunnya melalui kegiatan kelompok kerja guru yang dilaksanakan oleh dewan guru. Kurikulum dikembangkan sesuai dengan kondisi madrasah, budaya

madrasah, dan perkembangan ilmu pengetahuan. Pelaksanaan kurikulum 
dilakukan dengan menjadikan kurikulum sebagai acuan dan pedoman penyusunan rencana pelaksanaan pembelajaran.

Untuk pengembangan diri siswa di Madrasah Tsanawiyah Negeri 1 Watampone dibentuk Kegiatan ekstrakurikuler yang dapat diikuti di luar kegiatan pembelajaran. Jadi siswa di Madrasah Tsanawiyah Negeri 1 Watampone memiliki dua kegiatan alternatif untuk pengembangan diri yakni proses pembelajaran dan kegiatan ekstrakurikuler. Bagi siswa yang kurang mampu dalam mengikuti proses pembelajaran dan kegiatan ekstrakurikuler dilakukan kegiatan bimbingan konseling.

Kegiatan pemenuhan standar proses dilakukan dengan menyusun rencana pelaksanaan pembelajaran, pelaksanaan rencana pembelajaran, dan dilakukan pengawasan, evaluasi, serta supervisi. Rencana pelaksanaan pembelajaran disusun sebelum proses kegiatan pembelajaran dan disahkan oleh kepala madrasah. Rencana pelaksanaan pembelajaran merupakan acuan bagi guru dalam proses pembelajaran. Pembelajaran di kelas dilakukan dengan mengikuti kegiatan-kegiatan yang tertuang dalam rencana pembelajaran. Kepala Madrasah melakukan pengawasan dan evaluasi kepada guru yang melaksanakan kegiatan pembelajaran melalui kamera CCTV yang terpasang di setiap kelas.

Kegiatan pemenuhan standar komptensi lulusan dilakukan dengan membantu siswa memperoleh pengalaman belajar untuk bisa berpikir logis, kritis, kreatif, inofatif, cinta tanah air, dan melaksanakan kegiatan agama dengan baik. Agar siswa Madrasah Tsanawiyah Negeri 1 Watampone dapat berpikir logis dan kritis dilakukan melalui metode diskusi dalam setiap kegiatan pembelajaran. Melalui metode tersebut siswa di Madrasah Tsanawiyah Negeri 1 Watampone dilatih untuk bertanya dan menjawab pertanyaan dengan baik sehingga secara otomatis mereka dapat berpikir 
logis dan kritis. Kreatifitas dan inofatif siswa diwujudkan melalui kegiatankegiatan kesenian dan ekstrakurikuler. begitupun dengan kegiatan keagamaan diwujudkan dengan membentuk budaya madrasah seperti kewajiban shalat berjamaah di sekolah.

Kegiatan pemenuhan standar pendidik dan tenaga kependidikan di Madrasah Tsanawiyah Negeri 1 Watampone memuat tentang kualifikasi akademik, kompetensi pendidik dan tenaga kependidikan dan kemampuan manajerial kepala madrasah. Penerimaan dan penempatan guru dan tenaga kependidikan disesuaikan dengan kualifikasi dan latar belakang pendidikan, selain itu dilakukan juga tes kompetensi untuk memastikan kemampuan guru dan tenaga kependidikan sesuai dengan yang diharapkan. Meskipun masih didapatkan beberapa kekurangan seperti masih terdapat tenaga kependidikan yang memiliki kualifikasi ijasah yang tidak sesuai dengan bidang kerjanya, tetapi hal tersebut tidak begitu besar pengaruhnya terhadap peningkatan mutu madrasah bahkan kepala madrasah berusaha meningkatkan mutu tenaga pendidik dan tenaga kependidikannya melalui berbagai pelatihan.

\section{Kesimpulan}

Hasil penelitian ini memberikan gambaran tentang manajemen berbasis madrasah di Madrasah Tsanawiyah Negeri 1 Watampone dan manajemen berbasis madrasah dalam peningkatan mutu di Madrasah Tsanawiyah Negeri 1 Watampone. Berdasarkan hasil penelitian dan pembahasan, diperoleh beberapa kesimpulan sebagai berikut:

Manajemen berbasis madrasah di Madrasah Tsanawiyah Negeri 1 Watampone telah dilaksanakan dengan baik, melalui tahapan perencanaan dengan penyusunan program kerja dan rencana anggaran dengan melibatkan seluruh komponen madrasah yaitu kepala madrasah, semua wakil kepala madrasah, pendidik, tenaga kependidikan dan komite sekolah. Pelaksanaan 
program kerja dilakukan sesuai pembagian kerja masing-masing. Kepemimpinan madrasah dilaksanakan dengan baik oleh kepala madrasah selaku pimpinan di madrasah. Pengawasan serta evaluasi dilakukan untuk memastikan semua kegiatan dilaksanakan dengan baik dan sebagai acuan untuk perbaikan selanjutnya. Sistem informasi madrasah digunakan untuk memperoleh informasi terhadap perkembangan dunia pendidikan.

Manajemen berbasis madrasah dalam peningkatan mutu di Madrasah Tsanawiyah Negeri 1 Watampone dilakukan dengan memenuhi semua kriteria standar nasional pendidikan dan meningkatkan prestasi siswa. Dalam pemenuhan kriteria standar nasinonal pendidikan, dipastikan dengan melaksanakan semua kegiatan-kegiatan yang terkait dengan hal tersebut melalui kepemimpinan kepala madrasah yang kuat, kerjasama yang baik antara komponen madrasah, dan pemenuhan tugas dan tanggung jawab secara profesional.

\section{Daftar Rujukan}

Arikunto Suharsimi, Manajemen Penelitian, Jakarta: Rineka Cipta, 2005

Ahmad Dzaujak, Penunjuk Peningkatan Mutu pendidikan di sekolah Dasar, Jakarta: Depdikbud 1996

E. Mulyasa, Manajemen Berbasis Madrasah; Konsep, Strategi, Dan Implementasi, Bandung: Remaja Rosdakarya, 2004

Husaini Usman, Manajemen Teori, Praktik, dan Riset Pendidikan, Edisi 3. Cet. 11, Jakarta: Bumi Aksara, 2010

Iskandar Idy, Madrasah Sebagai Alternatif Peningkatan Mutu Madrasah; Studi Tentang Pengembangan Madrasah di Sulawesi Selatan "Tesis Magister” Makassar: PPs Universitas Muslim Indonesia, 2002 
Nanang Fatah, Konsep Manajemen berbasis Sekolah dan Dewan Sekolah. Bandung: Pustaka Bani Quraisy, 2003

Oemar Hamalik, Evaluasi kurikulum, Bandung: Remaja Rosda Karya,1990

Sudrajat, Implementasi Manajemen Berbasis Sekolah, Yogyakarta: Cipta Ilmu, 2014

Syaiful Sagala, Manajemen Strategik dalam Peningkatan Mutu Pendidikan, Bandung: Alfabeta, 2011

Tim, Peningkatan Manajemen Melalui Penguatan Tata Kelola dan Akuntabilitas di Sekolah/Madrasah, Jakarta: Kemendiknas dan Kemenag RI, 2011

UU RI No. 20 Tahun 2003, Tentang SISDIKNAS beserta penjelasannya, Surabaya: Media Center, 2005

Undang-undang Otonomi Daerah, Nomor 32 Tahun 2004 tentang Pemerintahan Daerah, Bandung: Fokusmedia, 2008

Yuliana Tety, Kemampuan Kepala Sekolah Dalam Implementasi Manajemen Peningkatan Mutu Berbasis Sekolah Studi Kasus di SMP Negeri 2 Brebes, Semarang: Tesis Manajemen Pendidikan, PPs Universitas Negeri Semarang, 2006. 